\title{
Spread Patterns of Antibiotic Resistance in Faecal Indicator Bacteria Contaminating an Urbanized Section of the Brda River
}

\author{
Łukasz Kubera ${ }^{1}$ (D) \\ Received: 1 September 2020 / Accepted: 14 October 2020 / Published online: 24 October 2020 \\ (C) The Author(s) 2020
}

\begin{abstract}
This paper presents the spatio-temporal distribution of faecal indicator bacteria (FIB) in the river section subject to anthropogenic stress and describes spread patterns of antibiotic resistance in the studied bacterial groups. The analysis involved 58 strains of Escherichia coli and 61 strains of enterococci. Antibiotic resistance profiles were prepared in accordance with the recommendations of the European Committee on Antimicrobial Susceptibility Testing (EUCAST). The results indicated a correlation between the location of a sampling site and the concentration of faecal bacteria. The highest average concentrations were recorded at the site located in the city centre, where the river is used mainly for recreation. Antibiotic resistance profiles showed that Escherichia coli had $100 \%$ sensitivity to tigecycline, levofloxacin and imipenem. The highest percentaage of strains (17\%) were resistant to piperacillin. Enterococci were 100\% sensitive to levofloxacin. No strains were vancomycin-resistant (VRE). The highest percentage of strains was resistant to imipenem (23\%), and the lowest, to ampicillin (2\%). The spatio-temporal distribution of antibiotic-resistant strains (ARS) indicated a high concentration of drug-resistant Escherichia coli (47\%) in the summer season at the sampling site located in the last part of the river. At the same time, drug resistance in enterococci increased along the river course and was considerably higher in spring. There were no significant relationships between physico-chemical parameters of water and the levels of faecal bacteria. On the other hand, strong relationships were observed between the percentage of strains showing resistance to the applied antibiotics and physico-chemical and biological parameters of water. The percentage of antibiotic resistant strains of Escherichia coli was negatively correlated with dissolved oxygen concentration $(r=-0.9 ; p<0.001)$ and $\mathrm{BOD}_{5}(r=-0.85 ; p<0.05)$. The percentage of antibiotic resistant strains of enterococci was most strongly correlated with water $\mathrm{pH}(r=-0.92 ; p<0.001)$.
\end{abstract}

Keywords Antimicrobial resistance $\cdot$ Faecal bacteria $\cdot$ Escherichia coli $\cdot$ Enterococci $\cdot$ River pollution

\section{Introduction}

Since the beginning of human settlement, rivers have played a key role in the development of towns and cities, ensuring the progress of civilization. Extremely important for agriculture and transport, they were also the recipient of municipal sewage [1]. Nowadays, aquatic ecosystems in urban areas are used mainly for recreation, contirbuting to the development of tourism [2]. As a result, they are often exposed to physical, chemical and biological contamination [3]. In summer, urban

Łukasz Kubera

kubera@ukw.edu.pl

1 Faculty of Biological Sciences, Department of Microbiology and Immunobiology, Kazimierz Wielki University, Al. Powstańców Wielkopolskich 10, 85-090 Bydgoszcz, Poland aquatic ecosystems are frequently used for bathing. However, places that are not officially established as bathing areas are not regularly monitored. The recreational use of such waterbodies against the official recommendations may lead to their ecological degradation and is an epidemiological threat. Another reason for microbiological monitoring of city watercourses is that they are often used by animals, and this can affect water quality, promoting the transmission of pathogenic microorganisms $[4,5]$. Since determining the concentration of all pathogens in water is simply impossible, the concentration of faecal indicator bacteria (FIB) is measured to detect and estimate the level of water contamination primarily with Escherichia coli and enterococci [6-8]. Nowadays, there is a growing concern about antimicrobial resistance of bacteria. The widespread use of antimicrobials in both medicine and agriculture has caused a dramatic increase in the number of drug-resistant bacterial strains in the natural environment. In 
surface waters, antibiotics are found at concentrations that significantly affect the activity of bacterial genes, leading, among others, to their increased mutation frequency [9]. This carries the risk of transferring resistance genes between pathogenic and non-pathogenic bacterial cells, and thus poses a direct danger to people [10]. Bacteria displaying resistance to nearly all available antibiotics were already found in anthropogenically impacted environments more than a decade ago [11].

Therefore, the present study is aimed at determining the concentration of faecal bacteria in the last, anthropogenically affected section of the Brda River and at evaluating their antimicrobial resistance. In addition, a number of environmental factors that may contribute to this increased drug resistance were identified and analysed.

\section{Materials and Methods}

\section{Study Area}

Located in the northern part of Poland, the Brda River is the left tributary of the Vistula, the longest river in Poland. It has the length of nearly $240 \mathrm{~km}$ and catchment area of approximately $4655.0 \mathrm{~km}^{2}$. The river flows through a patchwork of open fields and forest land in a predominantly agricultural setting. The last section cuts through the city of Bydgoszcz, where it is used for recreational purposes [12]. Bydgoszcz population is about 355,000 , with 2000 people per square kilometre on average.

\section{Sampling Strategy}

Three sampling sites were located in the studied area: (I) on the north-western border of the city, just before the river enters the city; (II) in the city centre, where the river is extensively used for recreation; (III) in the north-eastern part of the city, just before the confluence of the Brda and the Vistula. Between sampling sites I and II, there is a water pumping station. The distance between the sites was about $12 \mathrm{~km}$. The location of sampling sites is presented in Fig. 1. Sampling was conducted in a seasonal cycle: in spring (21.05.2018), summer (06.08.2018) and autumn (15.10.2018). Water from the mid-point of the river, depth of about $0.5 \mathrm{~m}$, was collected in triplicate to sterile bottles. The samples were immediately transported to the laboratory and analysed.

\section{Physico-Chemical Parameters of Water}

Physico-chemical parameters of water, including $\mathrm{pH}$, temperature (T), electrolytic conductivity (EC), and oxygen concentration (OC), were measured in situ using field probes (Mettler Toledo ${ }^{\mathrm{TM}}$ ). The results are presented in Table 1.

\section{Evaluation of Biochemical Oxygen Demand}

The biochemical oxygen demand $\left(\mathrm{BOD}_{5}\right)$ was measured to assess water quality at using the respirometric method and the OxiTop® Control system. This method is based on the measurement of the oxygen consumption by microorganisms during the decomposition of organic substances in a sealed sample, which is accompanied by a pressure change. Differences in oxygen consumption and carbon dioxide production resulting from the respiratory activity of bacteria are measured by OxiTop-C heads. The OxiTop OC 110 remote controller collects and interprets data using the built-in algorithm. To determine the in situ respiratory activity of planktonic bacteria, $250 \mathrm{~mL}$ of river water from each sampling site was poured into dark OxiTop bottles with a capacity of $500 \mathrm{~mL}$. Then, 5 drops of NTH 600 nitrification inhibitor and a magnetic stirrer were put in the bottles. After a rubber quiver with two tablets (about $0.4 \mathrm{~g}$ ) of sodium hydroxide (carbon dioxide absorber) was placed in each bottle neck, OxiTop-C measuring heads were tightly screwed on. The parameters were set on the controller, and the bottles were placed on a magnetic stirrer and incubated for 5 days at $+20^{\circ} \mathrm{C}$. The results are expressed as $m g \mathrm{O}_{2} \mathrm{~L}^{-1}$.

\section{Total Concentration of Faecal Bacteria}

Escherichia coli were calculated according to ISO 93081:2014, while enterococci, to ISO 7899-2:2000. ChromoCult@ Coliform Agar (CCA) selective medium was used to isolate Escherichia coli, while Slanetz and Bartley (SB) medium to detect and enumerate enterococci. In both cases, the membrane filtration method was used. The selected volumes of water samples were filtered through white filters with $47 \mathrm{~mm}$ diameter and $0.45 \mu \mathrm{m}$ pore size. The plates with filters were incubated for $24-48 \mathrm{~h}$ at $35 \pm 1{ }^{\circ} \mathrm{C}$. After that, grown colonies were counted and the concentration of faecal bacteria was expressed as CFU $100 \mathrm{~mL}^{-1}$.

\section{Antimicrobial Resistance Assessment}

Antibiotic resistance of faecal bacteria was determined using the disk diffusion method. Escherichia coli isolated from the CCA medium and enterococci isolated from the SB medium were used for the analysis. Strains used for the preparation of drug sensitivity profiles were checked for purity using API 20E and API ${ }^{\circledR} 20$ Strep test strips (bioMérieux, France). Antimicrobial resistance of Escherichia coli isolated $(n=58)$ from CCA medium and enterococci isolated $(n=61)$ from SB medium was determined using the disk diffusion method. Mueller-Hinton agar was inoculated with the volumes of 


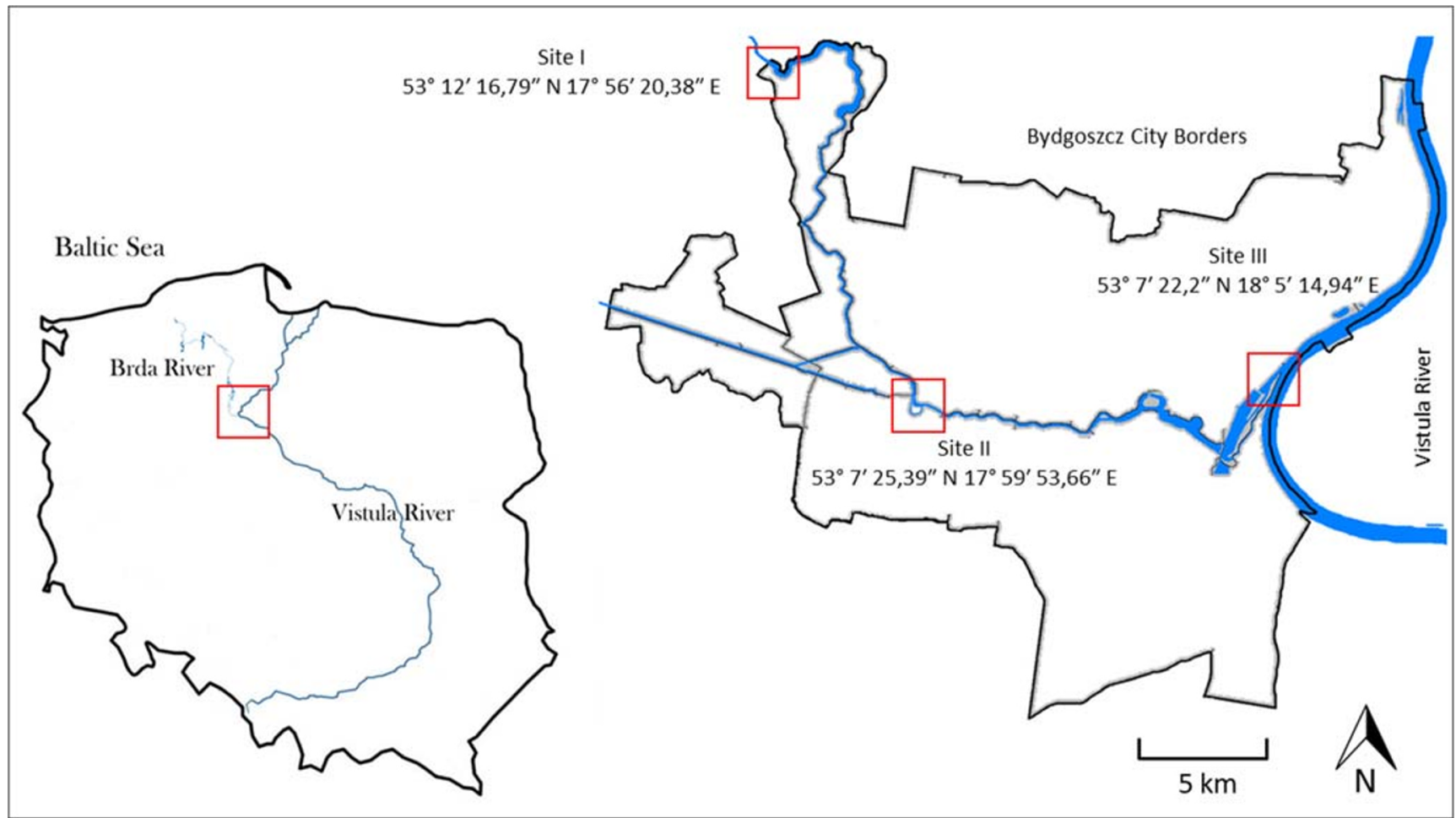

Fig. 1 Arrangement of the sampling sites. The rivers are marked in blue. The sampling sites are marked in red

$0.1 \mathrm{~mL}$ of bacterial suspension equivalent to $0.5 \mathrm{McF}$ arland turbidity standard. Subsequently, paper disks soaked with selected antibiotics were placed on the Petri dishes. After $18 \mathrm{~h}$ of incubation at $36^{\circ} \mathrm{C}$, zones of inhibited growth were measured and the results were compared with the guidelines of the European Committee on Antimicrobial Susceptibility Testing [13]. Characteristics of used antibiotics are presented in Table 2 .

\section{Statistical Analysis}

Due to the fact that the data were not normally distributed, the analyses were conducted using nonparametric tests. The analysis of difference in faecal indicator bacteria count between research sites and seasons was based on the Kruskal-Walis test (one-way ANOVA on ranks). Relationships between physicochemical parameter values and the counts of faecal indicator bacteria as well as ARS strains were determined using Spearman correlation coefficient. All statistical tests had a significance level $p \leq 0.05$.

\section{Results}

Faecal bacteria are the basic indicator of sanitary water quality in aquatic ecosystems. According to the results, all water samples contained faecal bacteria. Their highest average concentration was recorded at sampling site II located in the city
Table 1 Physico-chemical parameters of water. Results are presented as means \pm standard deviation

\begin{tabular}{llcccc}
\hline Site & Season & \multicolumn{1}{c}{$\mathrm{T}\left({ }^{\circ} \mathrm{C}\right)$} & $\mathrm{pH}$ & $\mathrm{EC}\left(\mu \mathrm{S} \mathrm{cm}^{-1}\right)$ & $\mathrm{OC}\left(\mathrm{mg} \mathrm{dm}^{-3}\right)$ \\
\hline I & Spring & $13.97 \pm 0.15$ & $7.21 \pm 0.56$ & $362.67 \pm 2.52$ & $5.39 \pm 0.04$ \\
& Summer & $18.67 \pm 0.06$ & $7.41 \pm 0.57$ & $334 \pm 1$ & $5.04 \pm 0.08$ \\
& Autumn & $15 \pm 0.14$ & $7.25 \pm 0.21$ & $311 \pm 5.66$ & $5.16 \pm 0.43$ \\
II & Spring & $16.73 \pm 0.23$ & $7.92 \pm 0.09$ & $380 \pm 2$ & $5.78 \pm 0.05$ \\
& Summer & $19.43 \pm 0.15$ & $7.91 \pm 0.06$ & $372.33 \pm 3.21$ & $5.86 \pm 0.05$ \\
& Autumn & $15.1 \pm 0$ & $7.9 \pm 0.05$ & $341.5 \pm 4.95$ & $4.77 \pm 0.97$ \\
III & Spring & $17.53 \pm 0.06$ & $7.96 \pm 0.03$ & $400 \pm 1$ & $5.69 \pm 0.04$ \\
& Summer & $19.5 \pm 0.1$ & $7.95 \pm 0.06$ & $387 \pm 3.61$ & $6.08 \pm 0.64$ \\
& Autumn & $16.95 \pm 0.07$ & $7.93 \pm 0.06$ & $232.5 \pm 6.36$ & $5.59 \pm 0.17$ \\
\hline
\end{tabular}

$T$ temperature, $E C$ electrolytic conductivity, $O C$ oxygen concentration 
Table 2 Characteristic of used antibiotics

\begin{tabular}{llll}
\hline Class of antibiotic & Type of antibiotic & Symbol of disk & Concentration $(\mu \mathrm{g})$ \\
\hline Carbapenems & Imipenem & IMP & 10 \\
Fluoroquinolones & Levofloxacin & LEV & 5 \\
Tetracyclines & Tigecycline & TGC & 15 \\
Glycopeptides & Vancomycin $^{\mathrm{a}}$ & VA & 5 \\
Penicillins & Ampicillin $^{\mathrm{a}}$ & AM & 2 \\
& Piperacillin $^{\mathrm{b}}$ & PRL & 30 \\
Cephalosporins & Cefoxitin $^{\mathrm{b}}$ & FOX & 30 \\
Aminoglycosides & Gentamicin $^{\mathrm{b}}$ & CN & 10 \\
\hline
\end{tabular}

${ }^{\text {a }}$ Only for enterococci

${ }^{\mathrm{b}}$ Only for Escherichia coli centre $\left(1744 \mathrm{CFU} 100 \mathrm{~mL}^{-1}\right.$ for Escherichia coli and $650 \mathrm{CFU} 100 \mathrm{~mL}^{-1}$ for enterococci), while the lowest, at sampling site I, i.e. before the river enters the city (189 CFU $100 \mathrm{~mL}^{-1}$ for Escherichia coli and $39 \mathrm{CFU} 100 \mathrm{~mL}^{-1}$ for enterococci) (Fig. 2a). The concentration of faecal bacteria depended on the season of the year; while it was similar in spring and summer, it increased considerably in autumn, reaching $2333 \mathrm{CFU} 100 \mathrm{~mL}^{-1}$ in case of Escherichia coli and $789 \mathrm{CFU} 100 \mathrm{~mL}^{-1}$ in case of enterococci (Fig. 2b). Statistical analysis indicated a strong relationship between both the location and season of the year and the concentration of the studied bacterial groups. Significant differences in the concentration of Escherichia coli $(p<0.05)$ were noted between sampling sites I and III and between spring/summer and autumn. The season of the year also affected the distribution of enterococci, with significant differences between spring and autumn.

Biological oxygen demand ranged from $1.8 \mathrm{mg} \mathrm{O}_{2} \mathrm{~L}^{-1}$ at sampling site $\mathrm{I}$ in autumn to $43.4 \mathrm{mg} \mathrm{O}_{2} \mathrm{~L}^{-1}$ at sampling site $\mathrm{III}$ in spring. Although $\mathrm{BOD}_{5}$ values increased along the river current, the differences were not statistically significant. On the other hand, a strong relationship was observed between the season of the year and the distribution of $\mathrm{BOD}_{5}$ : the highest average values were recorded in spring, while the lowest, in autumn. Multiple comparison tests indicated differences between these two seasons at the significance level $p<0.0001$ (Table 3).

Drug resistance profiles indicated that the majority of faecal strains were sensitive to the applied antibiotics. Escherichia coli (Fig. 3) were 100\% sensitive to tigecycline, levofloxacin and imipenem. The resistance to other antibiotics varied. The highest percentage of strains (17\%) showed resistance to piperacillin, the only antibiotic to which $5 \%$ of the strains were medium sensitive. Then, $12 \%$ of the strains were resistant to cefoxitin, and 3\% to gentamycin. All enterococci isolates (Fig. 4) showed complete sensitivity to levofloxacin and vancomycin. The highest number of enterococci were resistant to imipenem (23\%), while the lowest to ampicillin (2\%). Eleven percent of enterococci isolates showed resistance to tigecycline, while $20 \%$ were medium sensitive.

Figure 5 presents spatio-temporal distribution of strains which were resistant to at least one of the applied antibiotics. A high accumulation of antimicrobial-resistant strains of Escherichia coli strains (47\%) was recorded in summer at

a)
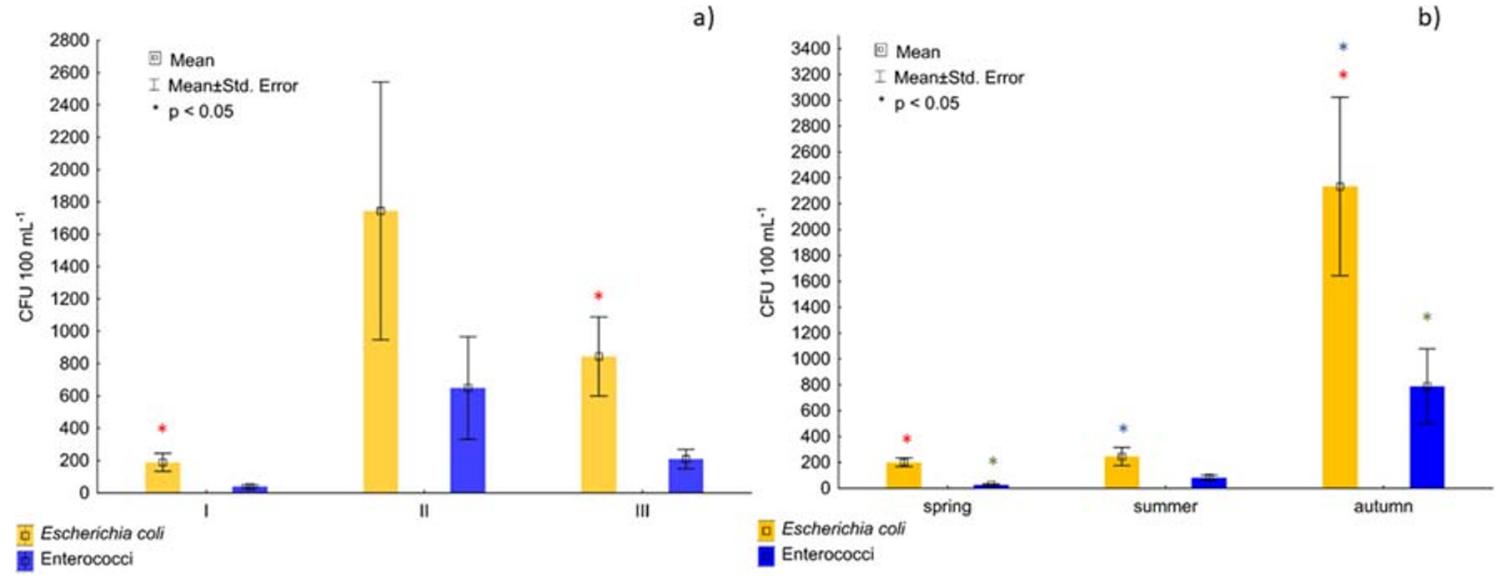

Fig. 2 Average number of faecal indicator bacteria $\mathbf{a}$ at the research sites, $\mathbf{b}$ in the research seasons. Statistical differences within groups of data was based on post hoc for Kruskal-Wallis test $(* p<0.05)$ 
Table 3 Results of $\mathrm{BOD}_{5}$ values expressed as $\mathrm{mg} \mathrm{O}_{2} \mathrm{~L}^{-1}$ and presented as means \pm standard deviation. Statistical differences within groups of data was based on post hoc for Kruskal-Wallis test

\begin{tabular}{lcrr}
\hline Season & \multicolumn{3}{l}{ Sampling sites } \\
\cline { 2 - 4 } & I & \multicolumn{1}{l}{ II } & \multicolumn{1}{l}{ III } \\
\hline Spring** & $27.19 \pm 14.09$ & $29.83 \pm 8.15$ & $43.40 \pm 0.00$ \\
Summer* & $18.97 \pm 12.43$ & $21.70 \pm 5.40$ & $26.23 \pm 7.85$ \\
Autumn**** & $1.80 \pm 1.56$ & $3.60 \pm 1.56$ & $4.53 \pm 5.68$ \\
\hline
\end{tabular}

$* p<0.05 ; * * p<0.0001$

sampling site III, the last part of the Brda River (Fig. 5a). At the same time, the number of resistant strains of enterococci increased along the river current and was highest in spring (Fig. 5b). None of the significant differences between the number of antibiotic resistant strains and sampling sites as well as between seasons were noted.

The study also examined the impact of selected environmental parameters on the concentration of faecal bacteria and the percentage of antibiotic resistant strains (ARS). As can be seen from Table 4, none of the parameters was significantly correlated with the total bacterial concentration. However, strong correlations were noted between the physico-chemical and biological parameters of water and the percentage of strains showing resistance to the tested antibiotics, e.g. the percentage of antimicrobial-resistant strains of Escherichia coli was negatively correlated with dissolved oxygen concentration $(r=-0.9 ; p<0.001)$ and $\mathrm{BOD}_{5}(r=-0.85 ; p<0.05)$. Similarly, there was a strong relationship between low oxygen concentration and the percentage of antibiotic-resistant strains of enterococci $(r=-0.73 ; p<0.05)$. However, the percentage of antibiotic-resistant enterococci isolates was most strongly correlated with water $\mathrm{pH}(r=-0.92 ; p<0.001)$.

\section{Discussion}

Rivers are dynamic, constantly evolving ecosystems, which undergo numerous changes as a result of natural processes and human activity. Since anthropopressure has such a significant impact on water quality in aquatic environments [14], a microbial assessment is necessary to reduce the risk from waterborne pathogens [6]. Moreover, high levels of faecal bacteria in surface waters, a common problem in urban areas, reduce their recreational values [15]. Microbiological analysis of the Brda River, flowing through a city of 350,000 , showed that the concentration of faecal bacteria depended on both the location of sampling sites and seasons of the year. The highest average concentrations of Escherichia coli and enterococci were recorded in cold and rainy autumn months. This dynamic increase could have resulted from different meteorological conditions after warm and sunny summer. Cho et al. [16] presented a model showing that sunlight and precipitation are key factors affecting FIB, with drought and strong sunlight limiting, and intensive rainfall, accelerating their growth. These relationships have also been confirmed by other researchers $[17,18]$. The analysis of the spatial distribution of faecal bacteria indicated that both Escherichia coli and enterococci were the least abundant at the sampling site located at the beginning of the studied section of the river. The average maximum values were recorded in the city centre and slightly lower, in the last part of the river. Although the concentration of FIB depended significantly on the location of sampling sites $(p>0.05)$, it did not increase along the river course.
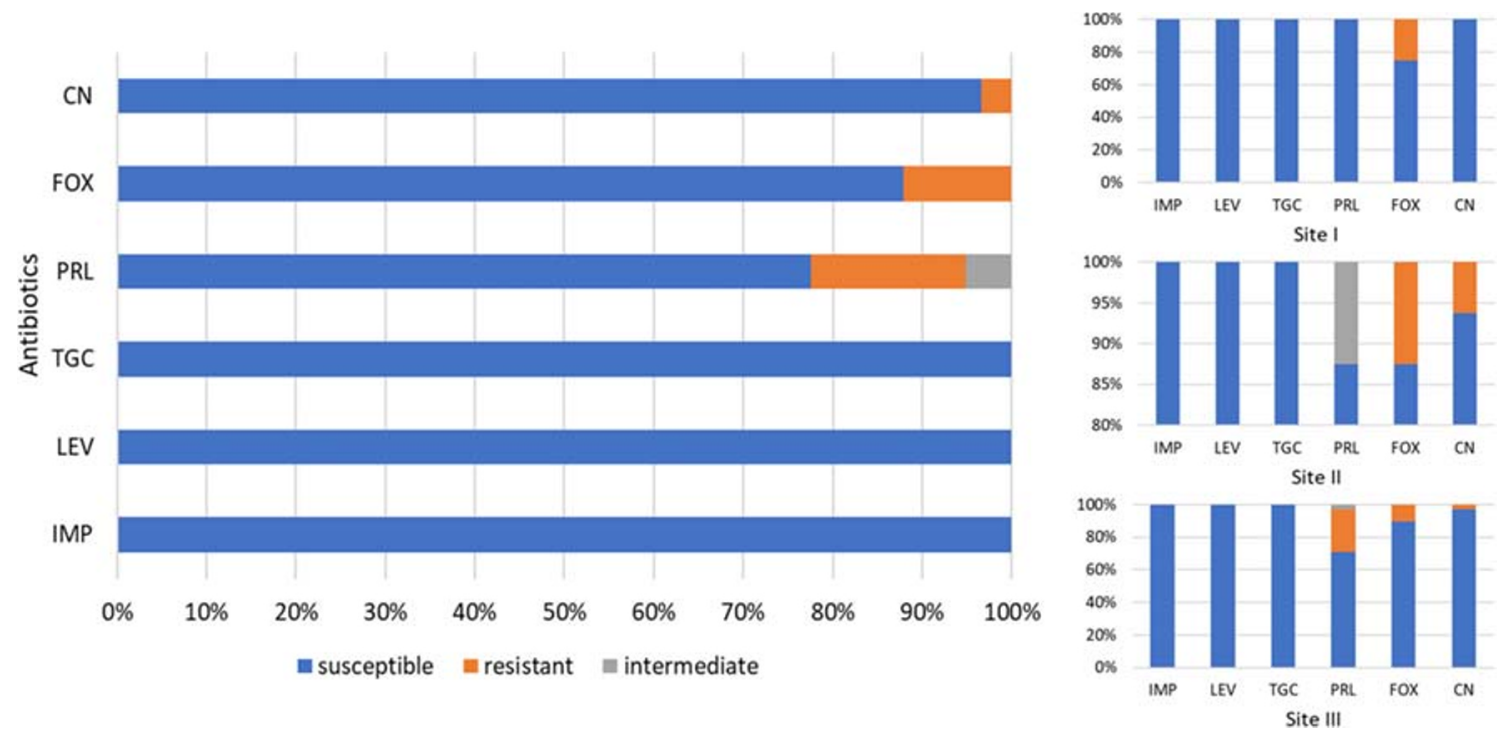

Fig. 3 Antimicrobial resistance of Escherichia coli strains $(n=58)$ divided into sampling sites. CN gentamicin, FOX cefoxitin, PRL piperacillin, TGC tigecycline, LEV levofloxacin, IMP imipenem 

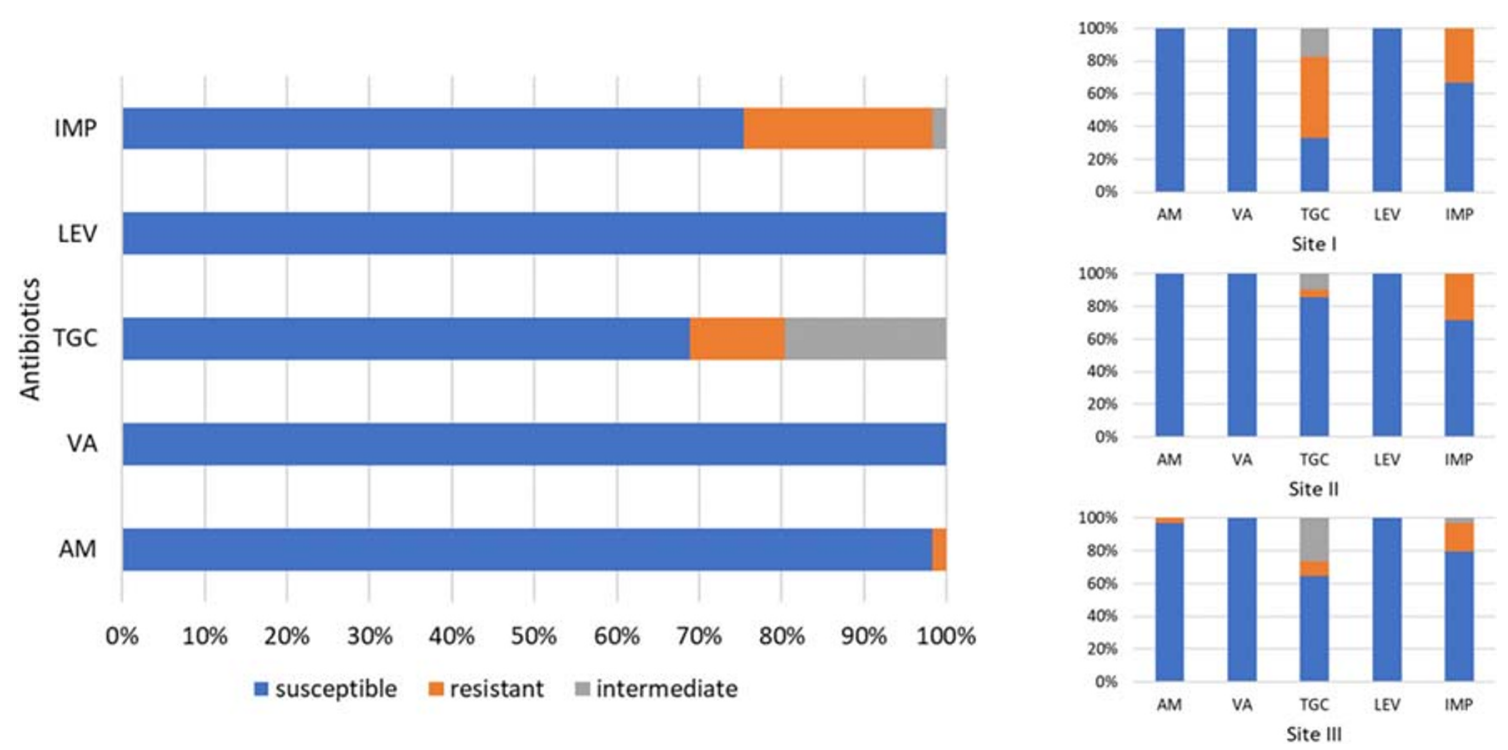

Fig. 4 Antimicrobial resistance of enterococci strains $(n=61)$ divided into sampling sites. IMP imipenem, LEV levofloxacin, TGC tigecycline, VA vancomycin, AM ampicillin

The observed growth at sampling site II was probably related to increased recreational activity in the city centre, featuring a beach and a water sports centre. However, high FIB concentration in this particular place can be attributed not only to the presence of people, but also animals. This part of the Brda River plays an important ecological role, providing habitat for many species of animals, including birds. Strauch [19], examining the impact of ecological factors on microbial quality of rivers in the Serengeti National Park in Tanzania, also maintained that animals could be the primary source of faecal bacteria in surface waters, which, especially in view of the increased demand for water resources, can pose a serious threat to human health. Nguyen et al. [20] found a positive correlation between FIB and a bird marker gene and pointed out that birds, not sewage, were the main source of faecal bacteria in examined samples. Although seasons of the year and changing weather conditions are two key factors affecting the concentration of faecal bacteria in surface waters, there are other environmental variables that can play an important role as well. Many studies have emphasized a correlation between FIB concentration and physico-chemical parameters of water. In the Betna River [21], the concentration of faecal bacteria was positively correlated with rainfall and water temperature. On the other hand, the results obtained by Wang et al. [22] showed no significant relationship between the levels of Escherichia coli and enterococci and any of the eleven physico-chemical parameters of water in the rivers of the Haihe river basin (China). In the present study, no significant influence of measured parameters on the size of FIB population was observed. Biochemical oxygen demand is among the most common criteria for assessing water quality [23]. It provides information to what extent a waterbody is contaminated with biodegradable organic matter [24]. High BOD loadings in freshwater ecosystems come mainly from anthropogenic sources, such as household and animal waste, industrial waste, and municipal sewage [25]. This may explain the relationship between Escherichia coli and $\mathrm{BOD}_{5}$. Thus, it can be concluded that for the studied section of the Brda River, the season and
Fig. 5 Spatio-temporal percentage distribution of antibiotic resistant strains (ARS): a Escherichia coli $(n=17)$; b enterococci $(n=22)$ (a)

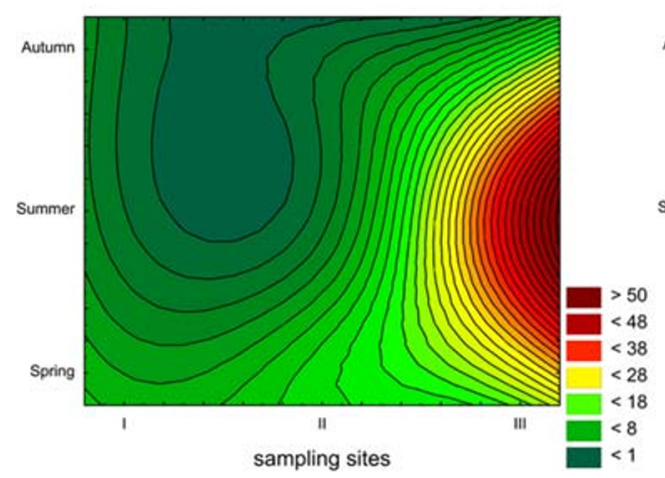

(b)

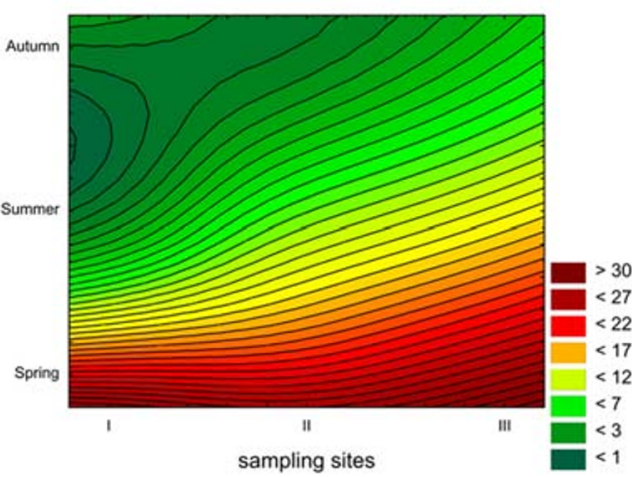


Table 4 Correlations between physico-chemical and biological parameters of water and total number of faecal bacteria including antibiotic resistance strains based on Spearman correlation coefficient

\begin{tabular}{|c|c|c|c|c|c|}
\hline & \multicolumn{5}{|c|}{ Correlation $(r)$} \\
\hline Escherichia coli & -0.13 & 0.37 & -0.16 & -0.08 & -0.40 \\
\hline ARS & -0.55 & -0.58 & $-0.82^{*}$ & $-0.90 * *$ & $-0.85^{*}$ \\
\hline Enterococci & 0.15 & 0.27 & -0.20 & -0.32 & -0.27 \\
\hline ARS & -0.53 & $-0.92 * *$ & $-0.70^{*}$ & $-0.73^{*}$ & -0.66 \\
\hline
\end{tabular}

$T$ temperature, $E C$ electrolytic conductivity, $O C$ oxygen concentration, $B O D_{5}$ biochemical oxygen demand, $A R S$ antibiotic resistance strains

${ }^{*} p<0.05 ; * *<0.001$ location of the sampling site were the only variables that significantly affected the growth of FIB. As has been already emphasized, aquatic ecosystems should be systematically monitored for sanitary water quality due to the potential epidemiological risk associated with the presence of faecal bacteria. This is of particular importance considering the functions of these ecosystems in urban environments and interactions between people and these ecosystems [26]. However, in the modern era of antibiotc abuse microbiological monitoring may be an insufficient measure. One of the key strategies to combat this increased antimicrobial resistance is to monitor the use of antibiotics and the spread of antimicrobial resistance [27]. Not only do antibiotic-resistant bacteria in natural waters pose a serious threat to humans and animals but they also impair the ecosystem functioning. Drug-resistant bacteria can affect the structural and functional diversity of microbial communities that play a key role in many ecological processes, particularly in those related to the maintenance of water quality [28]. My results suggested varied drug resistance among the studied FIB strains. Escherichia coli had the highest resistance to piperacillin $(17 \%)$, which is probably associated with their production of beta-lactamases that break the antibiotic structure. The production of these enzymes by Escherichia coli isolated from aquatic environments has been confirmed by many researchers [29-31]. All investigated Escherichia coli strains were sensitive to tigecycline, levofloxacin and imipenem. Resistance to the latter is very rare in environmental isolates [32]. In the study by Swedan and Alrub [33], Escherichia coli isolated from the sources of drinking water were also completely sensitive to imipenem and tigecycline. On the other hand, enterococci showed high resistance to imipenem: it was observed in $23 \%$ of the strains. However, no vancomycin-resistance strains (VRE) were identified. Veljović et al. [34] also observed complete sensitivity to vancomycin among enterococci isolated from aquatic ecosystems. At the same time, Alipour et al. [35] recorded vancomycin resistance only in 3 of 70 bacterial isolates representing four enterococcal species obtained from the aquatic environment. There were certain differences in spatio-temporal distribution of strains showing resistance to at least one of the applied antibiotics between the investigated bacterial groups. Antibiotic-resistant strains of Escherichia coli dominated in summer, with the highest percentage recorded in the lower course of the studied river section. On the other hand, antibiotic-resistant strains of enterococci dominated in spring, and their percentage increased gradually along the river course. Suzuki et al. [36], while examining resistance acquisition of Escherichia coli in the river environment, also observed an increased percentage of resistant strains at sampling sites located in the lower river course. Cho et al. [37] emphasize that antibiotic resistance is one of the biggest public health challenges of our time; therefore, more attention should be paid to the emergence and spread of antimicrobial resistance in aquatic environments. There is also a need for a better understanding of this phenomenon in humans and animals. Jia et al. [38] suggest that river ecosystems are natural reservoirs of antibiotic resistance genes, and that human activity contributes to the persistence of antibiotic contamination. Although research indicates that the natural environment is an important element in the transmission of resistant bacteria, these processes still need more recognition, especially at the ecological level [39]. Correlation analysis showed that although the measured environmental parameters did not affect the size of the faecal indicator bacteria population, they might have played a significant role in the development of their antibiotic resistance. Statistically significant negative correlations between the emergence of resistant strains and environmental variables such as oxygen concentration and electrolytic conductivity were recorded for both Escherichia coli and enterococci. Moreover, a strong relationship between water $\mathrm{pH}$ and the occurrence of resistant enterococcal strains was noted. So far, few studies have investigated the impact of environmental parameters on the increase of bacterial resistance in aquatic environments. Harnisz [40], who examined changes in resistance among indigenous bacteria in the river receiving treated sewage, also noticed negative correlations between water $\mathrm{pH}$ and oxygen concentration and antibiotic-resistant bacteria. Fletcher [41] maintains that understanding environmental factors is necessary to limit or prevent the spread of antibiotic resistance in the environment. Therefore, future research should confirm the observed relationships and determine whether 
environmental parameters can contribute to the development of mechanisms of antimicrobial resistance transmitted both vertically and horizontally.

\section{Conclusion}

In the current study, the faecal concentrations were correlated mainly with the season of the year and the location of sampling sites. Maximum concentrations were recorded in rainy autumn months at the sampling site affected by anthropopressure to the highest degree, which corresponds with the results of other studies. According to the prepared drug resistance profiles, the majority of faecal bacteria were sensitive to the applied antibiotics. The strains with varied resistance to the selected antimicrobials had different spatial distribution. Moreover, the results suggested the potential relationship between physico-chemical and biological parameters of water and increased drug resistance among faecal indicator bacteria. Further research, with the use of molecular tools, should be carried out to examine whether certain environmental variables can induce the expression of genes responsible for triggering antibiotic resistance in bacteria.

Funding This study was supported by the Polish Minister of Science and Higher Education, under the program "Regional Initiative of Excellence" in 2019-2022 (Grant No. 008/RID/2018/19).

\section{Compliance with Ethical Standards}

Conflict of Interest The author declares that there is no conflict of interest.

Open Access This article is licensed under a Creative Commons Attribution 4.0 International License, which permits use, sharing, adaptation, distribution and reproduction in any medium or format, as long as you give appropriate credit to the original author(s) and the source, provide a link to the Creative Commons licence, and indicate if changes were made. The images or other third party material in this article are included in the article's Creative Commons licence, unless indicated otherwise in a credit line to the material. If material is not included in the article's Creative Commons licence and your intended use is not permitted by statutory regulation or exceeds the permitted use, you will need to obtain permission directly from the copyright holder. To view a copy of this licence, visit http://creativecommons.org/licenses/by/4.0/.

\section{References}

1. Wolińska D, Sławiński K (2017) Significance changes of a river for urban space creation on the example of Cheonggyecheon stream in Seul. Research Papers of Wrocław University of Economics 467: 176-183. https://doi.org/10.15611/pn.2017.467.15

2. Stefanowska A (2014) The role of rivers in the development of urban tourism on the example of Warsaw and selected European cities. Turystyka Kulturowa 8:6-19
3. Tissera S, Lee SM (2013) Isolation of extended spectrum betalactamase (ESBL) producing bacteria from urban surface waters in Malaysia. Malays J Med Sci 20(3):14-22

4. López-Pila JM, Szewzyk R (2000) Estimating the infection risk in recreational waters from the faecal indicator concentration and from the ratio between pathogenes and indicators. Water Res 34(17): 4195-4200. https://doi.org/10.1016/S0043-1354(00)00197-4

5. Frak M, Nestorowicz A (2009) Sanitary assesment of selected water reservoir's in Warsaw parks. Scientific Review Engineering and Environmental Sciences 18(2):3-10

6. de Brauwere A, Ouattara NK, Servais P (2014) Modeling fecal indicator bacteria concentrations in natural surface waters: a review. Crit Rev Environ Sci Technol 44:2380-2453. https://doi.org/10. 1080/10643389.2013.829978

7. Sercu B, Van De Werfhorst LC, Murray JL, Holden PA (2011) Terrestrial sources homogenize bacterial water quality during rainfall in two urbanized watersheds in Santa Barbara, CA. Microb Ecol 62:574-583. https://doi.org/10.1007/s00248-011-9874-z

8. Januário AP, Afonso CN, Mendes S, Rodrigues MJ (2020) Faecal indicator bacteria and Pseudomonas aeruginosa in marine coastal waters: is there a relationship? Pathogens 9(1):13. https://doi.org/ $10.3390 /$ pathogens 9010013

9. Zabłotni A, Jaworski A (2014) Sources of antibiotics in natural environments and their biological role. Advances in Hygiene and Experimental Medicine 68:1040-1049. https://doi.org/10.5604/ 17322693.1119027

10. Costanzo SD, Murby J, Bates J (2005) Ecosystem response to antibiotic entering the aquatic environment. Mar Pollut Bull 51:218 223. https://doi.org/10.1016/j.marpolbul.2004.10.038

11. Kümmerer K (2004) Resistance in the environment. J Antimicrob Chemother 54:311-320. https://doi.org/10.1093/jac/dkh325

12. Radtke G, Bernaś R, Dębowski P, Morzuch J, Skóra M (2015) Fish fauna of the Brda river system. Scientific Annual of the Polish Angling Association 28:43-84

13. The European Committee on Antimicrobial Susceptibility Testing (2019) Breakpoint tables for interpretation of MICs and zone diameters. Version 9.0. http://www.eucast.org

14. Gotkowska-Płachta A, Gołaś I, Korzeniewska E, Koc J, Rochwerger A, Solarski K (2015) Evaluation of the distribution of fecal indicator bacteria in a river system depending on different types of land use in the southern watershed of the Baltic Sea. Environ Sci Pollut Res 23(5):4073-4085. https://doi.org/10.1007/ s11356-015-4442-6

15. Tiefenthaler LL, Stein ED, Lyon GS (2009) Fecal indicator bacteria (FIB) levels during dry weather from Southern California reference streams. Environ Monit Assess 155:477-492. https://doi.org/10. 1007/s10661-008-0450-Z

16. Cho KH, Cha SM, Kang JH, Lee SW, Park Y, Kim JW, Kim JH (2010) Meteorological effects on the levels of fecal indicator bacteria in an urban stream: a modeling approach. Water Res 44:21892202. https://doi.org/10.1016/j.watres.2009.12.051

17. Aragonés L, López I, Palazón A, López-Úbeda R, García C (2016) Evaluation of the quality of coastal bathing waters in Spain through fecal bacteria Escherichia coli and Enterococcus. Sci Total Environ 566-567:288-297. https://doi.org/10.1016/j.scitotenv.2016.05.106

18. Islam MMM, Sokolova E, Hofstra N (2018) Modelling of river faecal indicator bacteria dynamics as a basis for faecal contamination reduction. J Hydrol 563:1000-1008. https://doi.org/10.1016/j. jhydrol.2018.06.077

19. Strauch AM (2011) Seasonal variability in faecal bacteria of semiarid rivers in the Serengeti National Park, Tanzania. Mar Freshw Res 62:1191-1200. https://doi.org/10.1071/MF11075

20. Nguyen KH, Senay C, Young S, Nayak B, Lobos A, Conrad J, Harwood VJ (2018) Determination of wild animal sources of fecal indicator bacteria by microbial source tracking (MST) influences 
regulatory decisions. Water Res 144:424-434. https://doi.org/10. 1016/j.watres.2018.07.034

21. Islam MMM, Hofstra N, Islam MA (2017) The impact of environmental variables on faecal indicator bacteria in the Betna River basin, Bangladesh. Environ Process 4:319-332. https://doi.org/10. 1007/s40710-017-0239-6

22. Wang Y, Chen Y, Zheng X, Gui C, Wei Y (2017) Spatio-temporal distribution of fecal indicators in three rivers of the Haihe River Basin, China. Environ Sci Pollut Res 24(10):9036-9047. https:// doi.org/10.1007/s11356-015-5907-3

23. Jouanneau S, Recoules L, Durand MJ, Boukabache A, Picot V, Primault Y, Lakel A, Sengelin M, Barillon B, Thouand G (2014) Methods for assessing biochemical oxygen demand (BOD): a review. Water Res 49:62-82. https://doi.org/10.1016/j.watres.2013. 10.066

24. Kwak J, Khang B, Kim E, Kim H (2013) Estimation of biochemical oxygen demand based on dissolved organic carbon, UV absorption, and fluorescence measurements. J Chem 2013:243769-243769. https://doi.org/10.1155/2013/243769

25. Vigiak O, Grizzetti B, Udias-Moinelo A, Zanni M, Dorati C, Bouraoui F, Pistocchi A (2019) Predicting biochemical oxygen demand in European freshwater bodies. Sci Total Environ 666: 1089-1105. https://doi.org/10.1016/j.scitotenv.2019.02.252

26. Kubera $€$, Małecka-Adamowicz M (2017) Evaluation of sanitary and bacteriological condition of the "Balaton" water reservoir located in the center of Bydoszcz. Water-Environment-Rural Areas 57:63-73

27. WHO - World Health Organization (2014) Antimicrobial Resistance Global Report on Surveillance. World Health Organizations: Geneva, Switzerland

28. Grenni P, Ancona V, Caracciolo AB (2018) Ecological effects of antibiotics on natural ecosystems: a review. Microchem J 136:25-39. https://doi.org/10.1016/j.microc.2017.02.006

29. Zou LK, Li LW, Pan X, Tian GB, Luo Y, Wu Q, Li B, Cheng L, Xiao JJ, Hu S, Zhou Y, Pang YJ (2012) Molecular characterization of $\beta$-lactam-resistant Escherichia coli isolated from Fu River, China. World J Microbiol Biotechnol 28:1891-1899. https://doi. org/10.1007/s11274-011-0987-9

30. Yamashita N, Katakawa Y, Tanaka H (2017) Occurrence of antimicrobial resistance bacteria in the Yodo River basin, Japan and determination of beta-lactamases producing bacteria. Ecotoxicol Environ Saf 143:38-45. https://doi.org/10.1016/j.ecoenv.2017.04. 053

31. Lenart-Boroń A (2017) Antimicrobial resistance and prevalence of extended-spectrum beta-lactamase genes in Escherichia coli from major rivers in Podhale, southern Poland. Int J Environ Sci Technol 14:241-250. https://doi.org/10.1007/s13762-016-1155-4

32. Bessa LJ, Barbosa-Vasconcelos A, Mendes A, Vaz-Pires P, Martins da Costa P (2014) High prevalence of multidrug-resistant Escherichia coli and Enterococcus spp. in river water, upstream and downstream of a wastewater treatment plant. J Water Health 12(3): 426-435. https://doi.org/10.2166/wh.2014.160

33. Swedan S, Alrub HA (2019) Antimicrobial resistance, virulence factors, and pathotypes of Escherichia coli isolated from drinking water sources in Jordan. Pathogens 8(2):86. https://doi.org/10. 3390/pathogens 8020086

34. Veljović K, Popović N, Vidojević AT, Tolinački M, Mihajlović S, Jovčić B, Kojić M (2015) Environmental waters as a source of antibiotic-resistant Enterococcus species in Belgrade, Serbia. Environ Monit Assess 187:599. https://doi.org/10.1007/s10661015-4814-x

35. Alipour M, Hajiesmaili R, Talebjannat M, Yahyapour Y (2014) Identification and antimicrobial resistance of Enterococcus spp. isolated from the river and coastal waters in northern Iran. Sci World J 2014:287458. https://doi.org/10.1155/2014/287458

36. Suzuki Y, Hashimoto R, Xie H, Nishimura E, Nishiyama M, Nukazawa K, Ishii S (2019) Growth and antibiotic resistance acquisition of Escherichia coli in a river that receives treated sewage effluent. Sci Total Environ 690:696-704. https://doi.org/10.1016/j. scitotenv.2019.07.050

37. Cho S, Jackson CR, Frye JG (2020) The prevalence and antimicrobial resistance phenotypes of Salmonella, Escherichia coli and Enterococcus sp. in surface water. Lett Appl Microbiol 71:3-25. https://doi.org/10.1111/lam.13301

38. Jia J, Guan Y, Cheng M, Chen H, He J, Wang S, Wang Z (2018) Occurrence and distribution of antibiotics and antibiotic resistance genes in Ba River, China. Sci Total Environ 642:1136-1144. https://doi.org/10.1016/j.scitotenv.2018.06.149

39. Bengtsson-Palme J, Kristiansson E, Larsson DGJ (2018) Environmental factors influencing the development and spread of antibiotic resistance. FEMS Microbiol Rev 42(1):fux053. https:// doi.org/10.1093/femsre/fux053

40. Harnisz M (2013) Total resistance of native bacteria as an indicator of changes in the water environment. Environ Pollut 174:85-92. https://doi.org/10.1016/j.envpol.2012.11.005

41. Fletcher S (2015) Understanding the contribution of environmental factors in the spread of antimicrobial resistance. Environ Health Prev Med 20(4):243-252. https://doi.org/10.1007/s12199-015$0468-0$ 